\title{
California Energy Flow in 1994
}

\author{
I. Y. Borg \\ N. Mui
}

September 1996

This is an informal report intended primarily for internal or limited external distribution. The opinions and conclusions stated are those of the author and may or may not be those of the Laboratory.

Work performed under the auspices of the U.S. Department of Energy by the Lawrence Livermore National Laboratory under Contract W-7405-Eng-48. 


\section{DISCLAIMER}

This document was prepared as an account of work sponsored by an agency of the United States Government. Neither the United States Government nor the University of California nor any of their employees, makes any warranty, express or implied, or assumes any legal liability or responsibility for the accuracy, completeness, or usefulness of any information, apparatus, product, or process disclosed, or represents that its use would not infringe privately owned rights. Reference herein to any specific commercial product, process, or service by trade name, trademark, manufacturer, or otherwise, does not necessarily constitute or imply its endorsement, recommendation, or favoring by the United States Government or the University of California. The views and opinions of authors expressed herein do not necessarily state or reflect those of the United States Government or the University of California, and shall not be used for advertising or product endorsement purposes.

This report has been reproduced directly from the best available copy.

Available to DOE and DOE contractors from the Office of Scientific and Technical Information P.O. Box 62, Oak Ridge, TN 37831

Prices available from (615) 576-8401, FTS 626-8401

Available to the public from the National Technical Information Service

U.S. Department of Commerce 5285 Port Royal Rd. Springfield, VA 22161 
UCID-18991-94

CALIFORNIA ENERGY FLOW IN 1994

I. Y. Borg

N. Mui

September 1996 


\section{CONTENTS}

ABSTRACT 1

INTRODUCTION 2

CALIFORNIA ENERGY FLOW DIAGRAMS 2

CALIFORNIA'S ENERGY FLOW IN 1994 COMPARED TO 1993

$\begin{array}{ll}\text { The Economy } & 7\end{array}$

Energy Consumption $\quad 8$

TRANSPORTATION FUELS 11

$\begin{array}{ll}\text { Consumption } & 11\end{array}$

$\begin{array}{lr}\text { Alternative Fueled Vehicles } & 12\end{array}$

$\begin{array}{ll}\text { Vehicle Emission Standards } & 13\end{array}$

OIL AND NATURAL GAS PRODUCTION 14

$\begin{array}{ll}\text { Oil Production } & 14\end{array}$

$\begin{array}{ll}\text { Natural Gas Production } & 15\end{array}$

OIL AND NATURAL GAS SUPPLY 15

$\begin{array}{ll}\text { Oil Supply } & 15\end{array}$

Natural Gas Supply $\quad 16$

$\begin{array}{ll}\text { ELECTRICAL POWER } & 16\end{array}$

$\begin{array}{ll}\text { Source of Supply } & 16\end{array}$

Nuclear Power 16

Hydropower 18

Nonutility Generation $\quad 19$

$\begin{array}{ll}\text { Alternative Sources of Electricity } & 19\end{array}$

Geothermal 19

$\begin{array}{ll}\text { Solar Electricity } & 21\end{array}$

Windpower 21

Deregulation of the California Electric Power Industry 23

APPENDIX A. Data Sources for California Energy Supply (1994) 26

APPENDIX B. Data Sources for California End Uses (1994) 27

APPENDIX C. Energy Balance for 1994 (Figure 1) 28

APPENDIX D. Conversion Units and Assumed Conversion Efficiencies 29

REFERENCES 30 


\section{ABSTRACT}

California energy consumption increased in 1994 in keeping with a recovery from the previous mild recession years. Although unemployment remained above the national average, other indicators pointed to improved economic health. Increased energy use was registered principally in the residential/commercial and transportation end-use sectors. A cooler-than-usual winter and spring was reflected in increased consumption of natural gas, the principal space-heating fuel in the state. Because of low water levels behind state dams, utilities turned to natural gas for electrical generation and to increased imports from out-ofstate sources to meet demand. Other factors, such as smaller output from geothermal, biomass, and cogenerators, contributed to the need for the large increase in electrical supply from these two sources.

Nonetheless, petroleum dominated the supply side of the energy equation of the state in which transportation requirements comprise more than one-third of total energy demand. About half of the oil consumed derived from California production. Onshore production has been in slow decline; however, in 1994 the decrease was compensated for by increases from federal offshore fields. Until 1994 production had been limited by regulatory restrictions relating to the movement of the crude oil to onshore refineries.

State natural gas production remained at 1993 levels. The increased demand was met by larger imports from Canada through the recent expansion of Pacific Transmission Co.'s 804-mile pipeline.

Deregulation of the state's utilities moved ahead in 1994 when the California Public Utilities Commission issued its proposal on how to restructure the industry. Public hearings were conducted in which the chief issues were recovery of the utilities' capital investments, conflicts with the Public Utilities Policies Act, management of power transactions between new suppliers and former utility customers, and preservation of energy conservation programs currently sponsored by the utilities. The issues were not resolved at year-end, but the state's public utilities began to take steps to improve their

positions in a future competitive market by cutting costs, improving efficiencies at operating plants, and enlarging their nonutility interests. 


\section{INTRODUCTION}

California is the most populous state in the nation ( 32 million), and of the 50 states it has the largest gross state product, aggregate personal income, value added by manufacture, retail trade, crop value, and number of Department of Defense and NASA prime contracts. Yet it ranked 45th in per capita energy consumption in 1992, the last year for which comparative figures are available for all states. This is at $71 \%$ of the national average. Some part of this record can be attributed to the benign climate associated with the more populated areas of the state; however, another share can be attributed to decades of effort on the part of California agencies, such as the California Energy Commission and the California Public Utility Commission, to promote energy conservation in its many forms.

For the past 18 years, energy flow diagrams for the State of California have been prepared from available data by members of the Lawrence Livermore National Laboratory. ${ }^{1}$ They have proven to be useful tools in graphically expressing energy supply and use in the state as well as in illustrating the difference between particular years and between the state and the United States as a whole.

As far as is possible, similar data sources have been used to prepare the diagrams from year to year, and the same assumptions ${ }^{1 a-e}$ concerning conversion efficiencies have been made in order to minimize inconsistencies in the data and analyses. A reexamination of transportation efficiencies, ${ }^{2}$ especially those associated with highway vehicles, has led to the downward revision of the percent used in the figures presented here for 1993 and 1994. Sources of data used in this report are given in Appendices A and B. We continue to see differences in specific data for a given year reported by our principal sources: U.S. Department of Energy, Energy Information Administration, and the California Energy Commission. In particular, reported data on supply and usage in the industrial and commercial/residential end-use categories have varied between reporting agencies. However, revisions in the data subsequently published by both principal sources have brought them into closer agreement and are reflected in revised energy flow diagrams, one of which is included here.

This report is written on the basis of energy supply and demand, regulations, and circumstances as they existed in 1994 . We purposely do not include any developments that have occurred subsequent to 1994.

\section{CALIFORNIA ENERGY FLOW DIAGRAMS}

California energy flow diagrams for 1994 and 1993 are shown in Figures 1 and 2 respectively. For comparison, the U.S. energy flow for 1994 is shown in Figure $3 .^{2}$ Energy sources are shown on the left and energy consumption is shown on the right. The 


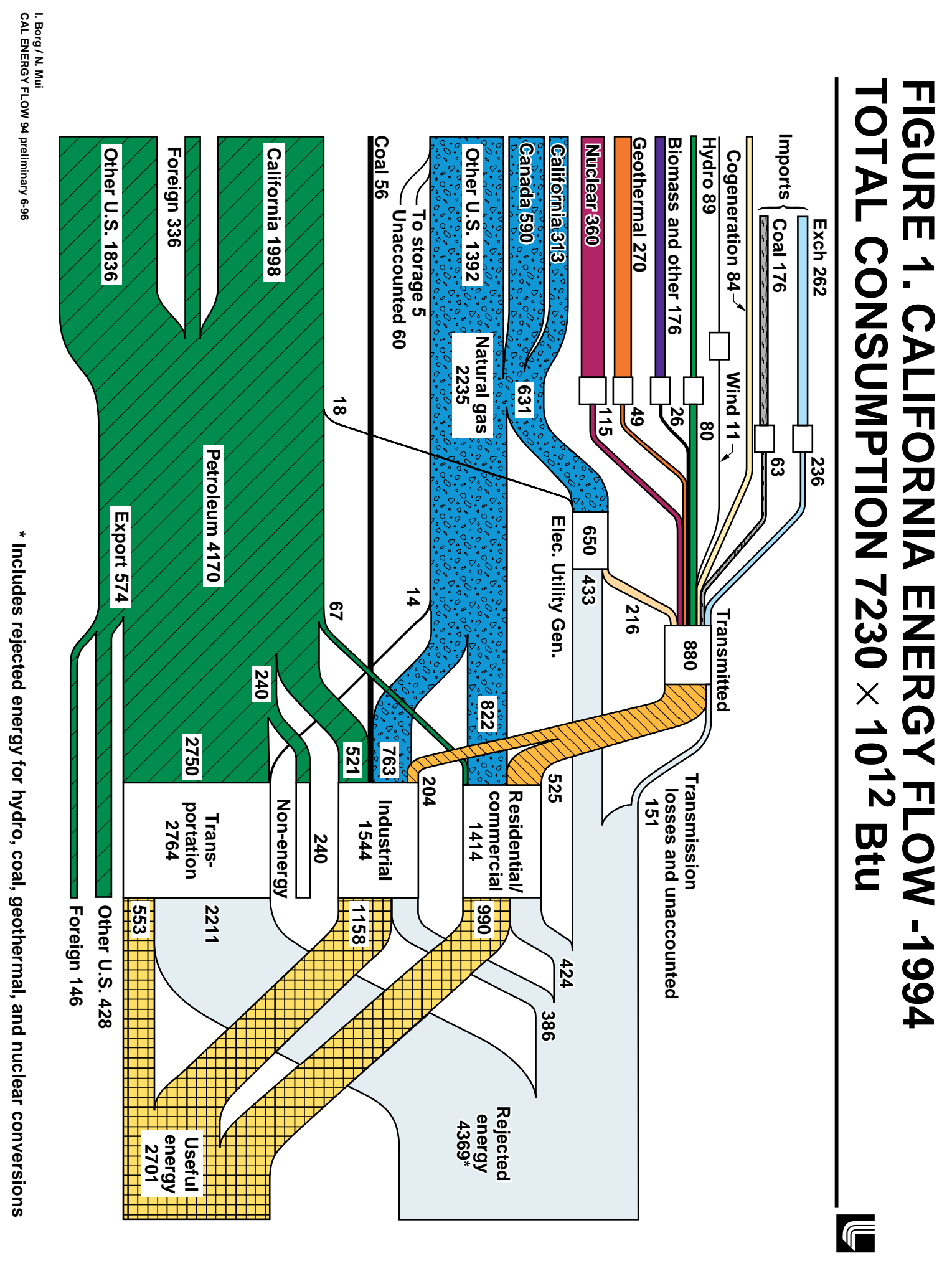




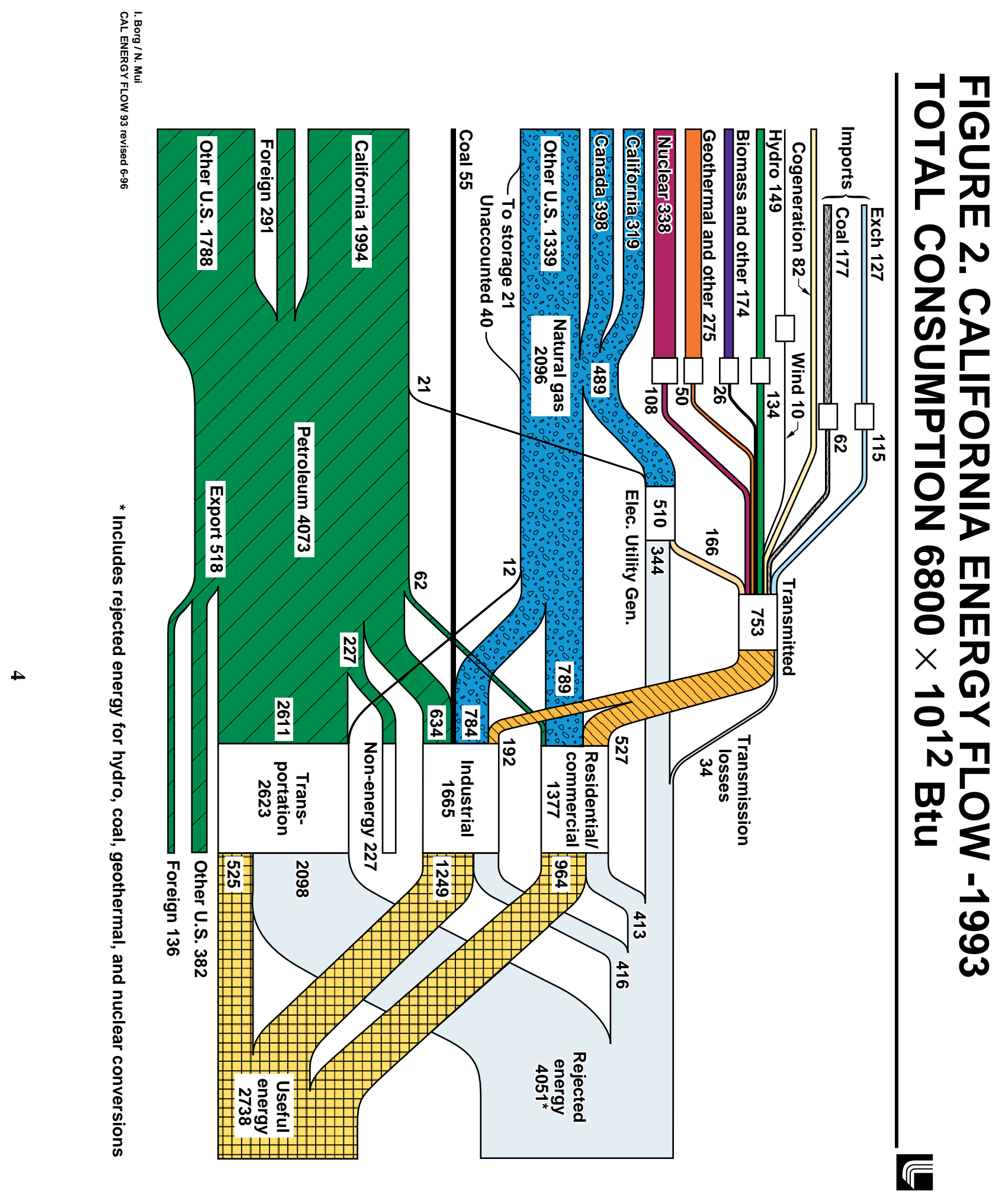



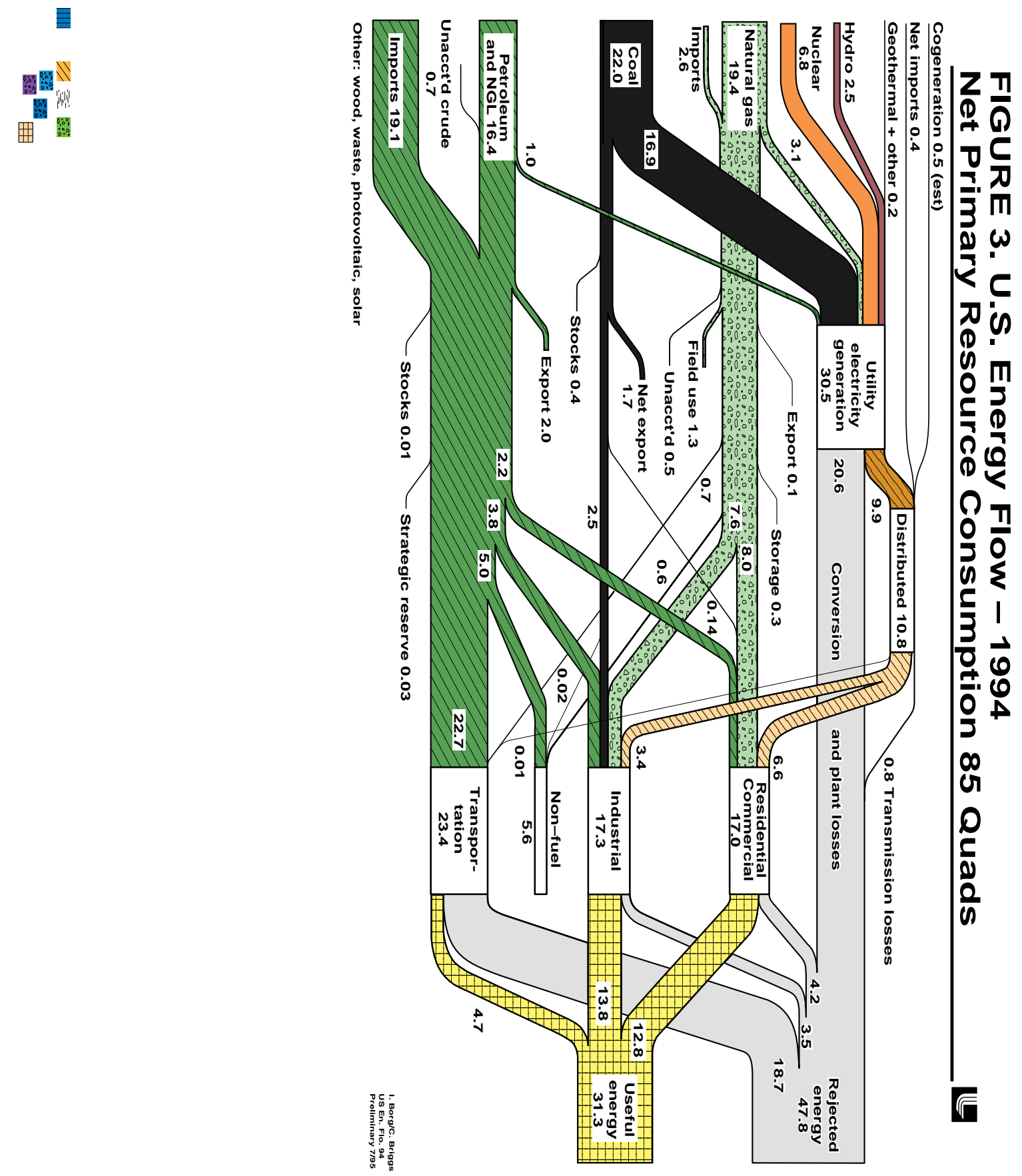
energy balance between the two is given in Appendix C. Also shown on the right of Figures 1, 2, and 3 is the division between "useful" and "rejected" energy based on estimates of conversion efficiencies in the various end-use sectors. "Rejected energy" consists primarily of heat losses. Conversion and plant losses at electric utility generation stations that burn fossil fuels are a matter of record, but inputs to total transmitted electricity such as nuclear and geothermal power, are associated with estimated efficiencies of the conversion process to electricity. These estimates vary from $90 \%$ in the case of hydroelectric power to $18 \%$ for geothermal energy. In 1993 we revised our estimate of efficiency for the transportation sector down from 25 to $20 \%$ after a review of the subject. ${ }^{2}$ The estimates of conversion efficiencies are given in Appendix D, and their rationales can be found in Ref. $1 b, 1 c$, and 2.

The box separating the energy source from the final electrical output represents the conversion process. In all cases the quantities associated with the energy source are calculated based on the assumed conversion efficiencies. While it is desirable to minimize the number of assumptions in preparing an energy flow diagram, it is also desirable to express as closely as possible the energy content of the sources used during the year. In this way it is possible to see at a glance which energy sectors are associated with the greatest conversion losses and are thus the largest targets for potential technological improvements in conversion efficiencies.

Power from cogenerators that is sold to utilities is shown in the figures as inputs to total transmitted electricity and appear without a box (representing the conversion process) that ordinarily would appear between the energy content of the fuel and the final product. In this instance, electric conversion losses are included in "rejected energy" from the industrial sector. Not shown in the flow diagrams is the amount of electricity used "in house" by the cogenerators and self-generators, but an estimate is given in the section on "Nonutility Generation." Thus the amount of electricity consumed by the industrial sector, $204 \times 10^{12}$ Btu in Figure 1, represents purchases from the utilities only.

Starting in 1992 the energy flow diagrams shown in Figures 1 and 2 reflect losses associated with electric conversions by the small independent power producers. Their collective sales of electricity to the utilities have been part of the public record and included in the charts; however, heretofore the fuels or type of energy used to produce electricity have not been available in a timely manner. Hence it has not been possible to estimate conversion losses. Generally the small power producers utilize energy sources, such as biomass or geothermal, whose conversion efficiency to electricity is lower than the conventional fossil fuels used for power production. The efficiency of fossil-fueled electric 
utility boilers is approximately 33\%, whereas the average efficiency of all biomass plants operated by nonutilities is approximately $12 \%,{ }^{3}$ and it is $18 \%$ for geothermal plants.

Electricity consumed by the residential/commercial end-use sectors shown in Figures 1 and 2 includes an "other" category of consumption tabulated by the U.S. Department of Energy. It includes street and highway lighting and other sales to public authorities, as well as sales to public railroads and railways. Lacking a breakdown in the "other," it is not possible to indicate how much of this electricity properly belongs in the transportation sector.

\section{CALIFORNIA’S ENERGY FLOW IN 1994 COMPARED TO 1993 \\ The Economy}

In 1994 California was in the midst of a solid recovery from a recession that ended in 1993. ${ }^{4}$ Most economic indicators showed impressive, positive gains by year-end (Table 1). Nonetheless the unemployment in the state during 1994-8.6\%-was high

\section{Table 1. Selected economic data for California-1994.}

\section{Indicator}

Unemployment

Housing units authorized

New auto registrations

Total taxable sales

Personal income

Consumer price index
Percent change from 1993

$-6.5$

$+14.4$

$+3.7$

$+4.5$

$+2.8$

$+1.4$

compared to the national average of $7.1 \% .^{5}$ Among the 50 states, only West Virginia had a higher unemployment rate. The unemployment in the state reflects continued reductions in federal defense spending and a shrinking aerospace industry, which cut 40,000 jobs in 1994.

Another indicator of economic activity, the number of new construction projects started during 1994 (Table 2), similarly points to the end of recession in the state. Despite rising interest rates, the number of building sales and new construction permits rose. Commercial lending by the state's major banks also increased after a three-year decline. 
Table 2. Construction authorized by permit-1994. (Value in millions of dollars)

\begin{tabular}{cccc}
\hline Year & Residential & \multicolumn{2}{c}{ Nonresidential } \\
& & Commercial & Other* \\
1988 & 26,361 & 6,569 & 7,592 \\
1989 & 27,790 & 6,159 & 7,507 \\
1990 & 20,686 & 5,270 & 7,466 \\
1991 & 15,056 & 3,374 & 6,247 \\
1992 & 14,451 & 2,472 & 5,683 \\
1993 & 12,932 & 2,137 & 5,420 \\
1994 & 14,823 & 2,019 & 5,762 \\
\hline
\end{tabular}

*Other consists of all other categories including additions and alterations of $\$ 100,000$ or more.

Inflation in California, which traditionally exceeds the national average, lagged the U.S. average of $2.7 \%$ by more than a percent (Table 1). The California consumer price index is a weighted average of published indexes for the Los Angeles and San Francisco Bay areas.

\section{Energy Consumption}

In response to an improved economic situation and a cooler winter, total energy consumption increased by $6 \%$ in 1994 . Comparison of components of California energy supply and demand for the past decade are given in Table 3. The weather indicators for principal metropolitan centers are given in Table 4.

The increase in energy demand was met by increased consumption of natural gas. This was made possible by the 1993 opening of two new major pipelines into the state that carry natural gas from Western Canada and from the Southwest.

The residential/commercial sector increased its gas use by $4 \%$, reflecting greater space-heating requirements. An even larger increase in the use of natural gas was registered by the electric power industry. Electric demand as measured by the amount of transmitted electricity rose a hefty $17 \%$. In view of the greater demand and the below-normal amount of hydropower available during the year, the utilities increased the amount of out-of-state imports and their gas-fired electrical generation. The amount of imported power and gas 


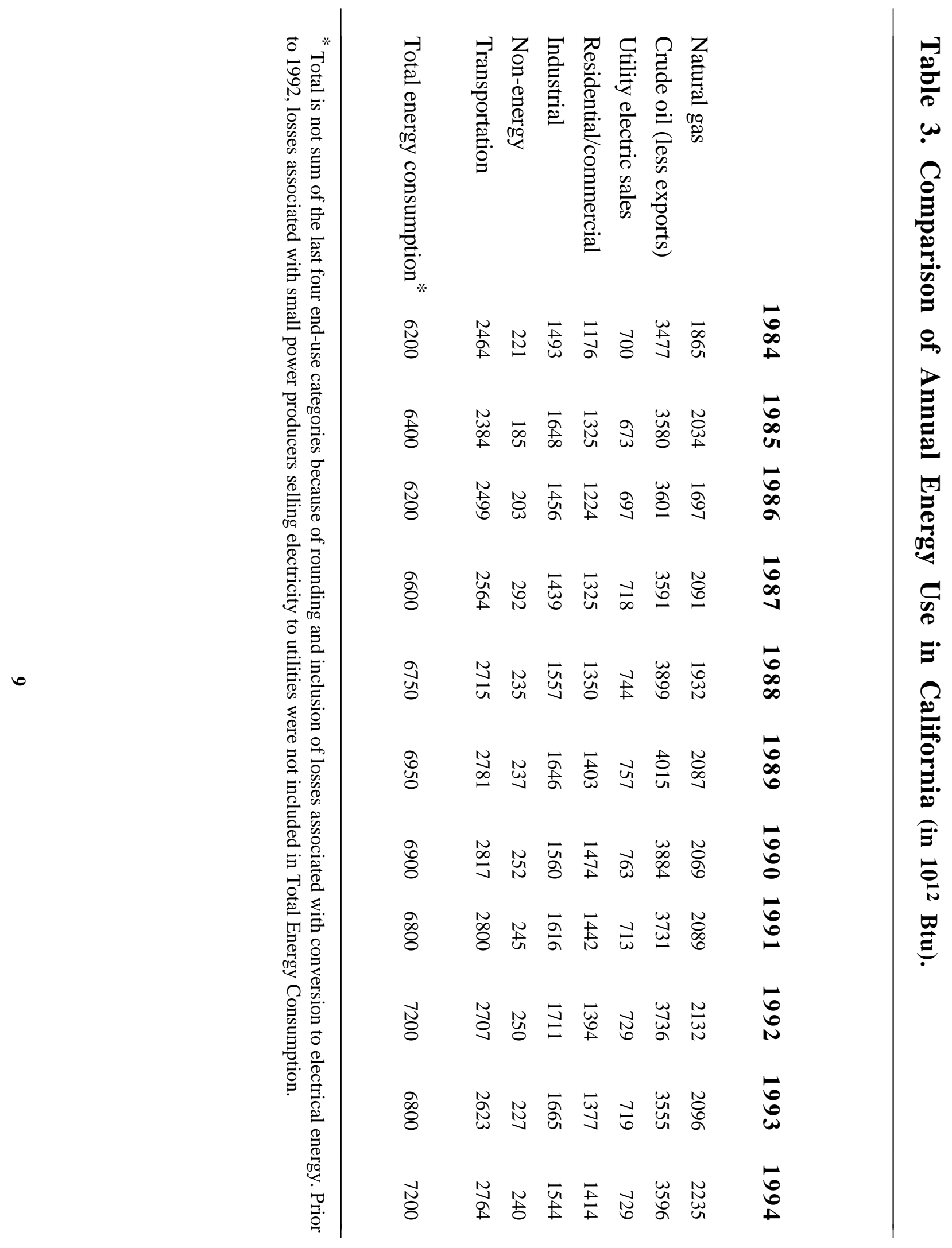


Table 4. Weather Comparison. 1968-1994 Annual Heating Degree Days*

\begin{tabular}{|c|c|c|c|}
\hline & $\begin{array}{l}\text { San Francisco } \\
\text { Federal Office } \\
\text { Building }\end{array}$ & $\begin{array}{l}\text { Los Angeles } \\
\text { Civic Center }\end{array}$ & $\begin{array}{c}\text { San Diego } \\
\text { Lindbergh } \\
\text { Field }\end{array}$ \\
\hline 1968 & 2942 & 850 & 1052 \\
\hline 1969 & 3066 & 1032 & 1145 \\
\hline 1970 & 3006 & 941 & 1137 \\
\hline 1971 & 3468 & 1424 & 1657 \\
\hline 1972 & 3240 & 918 & 1166 \\
\hline 1973 & 3161 & 1066 & 1137 \\
\hline 1974 & 3182 & 1084 & 1123 \\
\hline 1975 & 3313 & 1548 & 1416 \\
\hline 1976 & 2665 & 1128 & 793 \\
\hline 1977 & 2888 & 911 & 747 \\
\hline 1978 & 2599 & 1208 & 736 \\
\hline 1979 & 2545 & 1160 & 902 \\
\hline 1980 & 2799 & 597 & 590 \\
\hline 1981 & 2819 & 506 & 573 \\
\hline 1982 & 3195 & 975 & 913 \\
\hline 1983 & 2386 & 602 & 623 \\
\hline 1984 & $2648 * *$ & 704 & 713 \\
\hline 1985 & $2486 * *$ & 921 & 1079 \\
\hline 1986 & $1842 * *$ & 473 & 843 \\
\hline 1987 & $2150 * *$ & 979 & 1201 \\
\hline 1988 & $2194 * *$ & 867 & 1102 \\
\hline 1989 & $2526 * *$ & 844 & 1068 \\
\hline 1990 & $2340 * *$ & 839 & 1172 \\
\hline 1991 & $2422 * *$ & 879 & 1212 \\
\hline 1992 & $1718 * *$ & 705 & 866 \\
\hline 1993 & $2071 * *$ & 680 & 948 \\
\hline 1994 & $2670 * *$ & 733 & 1335 \\
\hline \multicolumn{4}{|l|}{ Normal } \\
\hline $1951-80$ & 2750 & 1204 & 1284 \\
\hline
\end{tabular}


*A "degree day" is a term that describes the relationship of energy consumption to outdoor temperatures. "Heating or cooling degree days" are deviations of the mean daily temperature from $65^{\circ} \mathrm{F}$. For example, for a day with a mean temperature of $40^{\circ} \mathrm{F}$, the "heating degree days" would be 25 and the "cooling degree days" 0 . Annual heating degree days are the sum for the year. Greater number of heating degree days means greater fuel requirements.

**CA. Mission Dolores - same historical data as for Federal Office Building

***Revised 1993.

Source: Local Climatological Data for San Francisco, Los Angeles and San Diego, National Oceanic and Atmospheric Admin., National Climatic Data, Asheville, NC. 
burned rose $105 \%$ and $29 \%$ respectively. The amount of cogenerated electricity sold to the utilities increased slightly and remained an important source of power for the utilities.

Industrial and related non-energy uses decreased 5\% in 1994. "Non-energy" is a designation for products produced from fossil fuels — such as petrochemicals, fertilizers, waxes, lubrication oils, and asphalt,- - that are not burned to produce energy. Asphalt, a by-product of the state's petroleum refining industry, is the principal constituent of the "non-energy" category in California.

Demand for transportation fuels, the bête noire of conservationists in California, increased a modest few percent. A breakdown of the consumption of transportation fuels 1988-1994 is given in the "Transportation Fuels" section that follows. Sales of gasoline actually fell, but increased use of diesel and aviation fuels more than compensated for the decline. Increased sales of bunkering fuels contributed to the overall increase in demand for transportation fuels as a group.

\section{TRANSPORTATION FUELS}

\section{Consumption}

For the 20th consecutive year, travel on the California state highway system was up $(1.26 \%) .^{6}$ In keeping with the increase in travel, sales of taxable gasoline and diesel fuels and registrations of new automobiles and commercial vehicles also increased. Noteworthy was the relatively large increase $(6.9 \%)$ in the number of new commercial vehicle registrations, reflecting the growing popularity of trucks, vans, recreational and off-road vehicles as well as improvement of the economic health of the state's businesses in 1994.

Bus ridership as reported by the 11 major operators within metropolitan areas fell for the third year in a row. ${ }^{6}$ Intercity bus travel fell by almost $14 \%$. Riders on ferries and intercity and commuter rail systems in the state also decreased. Although there were a few rail systems that had an increased number of passengers-e.g., Caltrain on the San Francisco Peninsula and Sacramento's Metro- the loss in 1994 of one million passengers on the Bay Area Rapid Transit system, the largest system in the state, more than compensated for the increases.

Air traffic, both private and commercial, showed a substantial increase that was reflected in increased sales of aviation gasoline and jet fuels.

The sale of bunkering fuels at California ports showed a marked increase (Table 5) but did not reach pre-1991 levels. The decline beginning in 1991 reflected the imposition of new state taxes that sent the shipping trade to other West Coast ports for fuels.

Table 5. California transportation end-use (in $10^{12}$ Btu). 


\section{$\begin{array}{lllllll}1988 & 1989 & 1990 & 1991 & 1992 & 1993 & 1994\end{array}$}

Net gasoline*

$1612 \quad 1630$

1664

1712

1670

1681

1626

Net aviation fuel

$427 \quad 458$

475

476

510

520

565

Taxable diesel fuel

244

265

253

246

256

253

275

- public highways

Rail diesel

$\begin{array}{rr}26 & 30 \\ 357 & 348 \\ 29 & 30\end{array}$

31

33

30

27

29

Net bunkering fuel

344

288

202

193

237

Military

20

29

26

23

7

18

Natural gas-pipeline

20

21

19

16

12

13

Natural gas vehicular

$\begin{array}{rrrrrrr}- & - & 0.004 & 0.01 & 0.03 & 0.27 & 0.58 \\ 2715 & 2781 & 2817 & 2800 & 2707 & 2693 & 2764\end{array}$

* As of January 1, 1992, leaded gas was no longer produced at California refineries.

** Some electricity is used for mass transit; however, the amount is not monitored on a statewide basis and hence does not appear in this table or in Figures 1 and 2.

Source: Fuel and Kerosene Sales-1994, DOE/EIA-0535(94), U.S. Department of Energy, Washington, DC (September 1994); Quarterly Oil Report, Annual Issue 1994 (Net gasoline and aviation fuel), California Energy Commission, Sacramento, CA (May 1996); Natural Gas Annual-1994, DOE/EIA-0131(93) Table 52, U.S. Department of Energy, Washington, DC (November 1995).

\section{Alternative Fueled Vehicles}

For 15 years the California Energy Commission (CEC) has actively supported the development of alternative fuel vehicles (AFV) by conducting demonstrations and addressing issues that represent barriers to greater U.S. use of alternative fuels. Alternative fueled vehicles play a minor role in the state's transportation system. Table 6 summarizes the CEC's estimate of the size of the California AFV fleet in 1994. ${ }^{7}$

According to a CEC staff report, the largest impediment to increased market penetration of $\mathrm{AFVs}$ is lack of infrastructure to fuel (or recharge), service, and support such vehicles.

Table 6. California alternative fueled vehicle fleet, $1994{ }^{7}$

Fuel
Vehicles in use

Cents per mile* 
Methanol

Compressed natural gas

Liquid petroleum gas

Electricity
6500

508

56,000

2,877
3.4

2.8

3.5

2.4

* Cost/mile is based on the gasoline equivalent price. Cost/mile for gasoline is 2.7 cents per mile in 1994 . $\mathrm{Cost} / \mathrm{mile}$ for electricity is based on off-peak power cost.

\section{Vehicle Emission Standards}

In May 1994, the California Air Resource Board (CARB) upheld its 1990 ruling that by 1998 two percent of the vehicles sold in the state will emit zero pollutants. In the interim, Massachusetts and New York have adopted, and nine other states are considering adopting, similar rules. In California, the required number to be sold escalates to 5\% in 2001 and $10 \%$ in 2003. Because 1,294,300 new automobiles were sold in California in $1994,{ }^{7}$ the $2 \%$ rule is tantamount to the sale of 30,000 to 40,000 electric or battery-operated vehicles. Although the auto industry has lobbied vigorously against the rule for five years, most were preparing to launch a lead-acid battery car in California in 1998. The principal argument advanced by the industry is that the battery technology is not sufficiently advanced to provide the driving range or comforts, such as heating and air conditioning, that customers demand at a price they can afford. They also argue that the additional electricity needed to operate the vehicles in the end will require the burning of additional fossil fuels, thereby causing additional pollution. In California the argument is not persuasive because electrical production in the state does not rely on the principal polluting fossil fuels (coal and oil) (Figure 1), and additional electrical demand in the past has been met by imports from neighboring states. Further, the CARB rule was formulated specifically to lower smog in populated areas where the chief source of pollution is vehicle exhaust containing hydrocarbons, NOx and CO.

On another front, state refineries were struggling to meet CARB and federal deadlines for the production of reformulated gasoline for sale in nonattainment areas, such as the Los Angeles basin. Production of reformulated gasoline requires boosting oxygen; lowering vapor pressure; reducing benzene, olefins, aromatics and sulfur; and adjusting distillation temperatures. The design is to reduce volatile organic compounds, $\mathrm{NOx}$, and air toxics. The capital cost of refinery modifications collectively exceed $\$ 1$ billion. ${ }^{8}$ The federal Phase I reformulated gasoline specifications are provisions of the 1990 Clean Air Act amendments to come into play January 1 , 1995. Phase II of the CARB specifications go into effect March 1, 1996. The CARB requirements in both Phase I and II are generally tougher than their federal counterparts. By the time the federal program peaks in 2000, California will have been subject to more stringent requirements for four years. CARB's Phase II regulations exceed those in Phase II of the federal program. Because not 
all gasoline produced in California stays in the state, even in Southern California not all refineries have opted to produce the modified fuel.

\section{OIL AND NATURAL GAS PRODUCTION}

\section{Oil Production}

California is the fourth largest oil producer in the nation, behind Texas, Alaska, and Louisiana. As expected, onshore production continued to decline in 1994, and the combined onshore and offshore production was $81 \%$ of the record high reached in 1985 . The largest declines were registered in the state's largest fields, Midwest-Sunset and South Belridge in Kern County. Both of these heavy oil fields depend heavily on steam injection for production. ${ }^{9}$ Collectively 652 wells were plugged and abandoned in the two fields.

Production at the Elk Hills field, which was designated Naval Petroleum Reserve No. 1 to ensure a supply of oil for the U.S. Navy by President Taft in 1912, was slightly up from 1993. It is the fifth largest producing oil field in the state; $78 \%$ of the field is owned by the federal government, with the remainder owned and operated by Chevron U.S.A. Production Co. That share is administered by the U.S. Department of Energy and managed and operated under a contract with Bechtel Petroleum Operations. During the year, the 42.5-MW Elk Hills Cogeneration Facility began operating, bringing the district's cogeneration capacity to $1.64 \mathrm{GW} .{ }^{9}$ The steamproducing cogeneration facilities are fueled by natural gas that is brought in by pipeline from outof-state sources. Surplus electricity is sold to a public utility.

One continuing bright note in the California oil production picture has been increased output from federal offshore fields that lie 3 to 200 miles from the coast. Two standouts were the Point Arguello and the Pescado field in the Santa Ynez Unit west of Santa Barbara. Increase in production in these two fields more than compensated for the drop in production from onshore and state offshore fields. In 1994 Chevron, which owns and operates the Point Arguello offshore field, lost its interim tankering permit, which was contingent on finalizing an agreement with an onshore pipeline to carry the field's crude oil. ${ }^{10}$ The permit allowed Chevron to tanker its crude directly to Los Angeles refineries rather than piping it in existing pipelines to northern California and Texas refineries, which have limited capacity to utilize heavy oils. Adding to the transportation bottleneck for offshore oil was the January 1994 Northridge earthquake, which shut down the Four Corners No. 1 pipeline to Los Angeles, and the increased production from Exxon's Pescado field. In view of the fact that plans for a 130,000-barrel/day pipeline from central California to Los Angeles refineries (Pacific Pipeline System, Inc.) were moving ahead, Chevron applied again for an interim tanker permit, contending that the conditions of the original interim tanker permit had been met. The Pacific Pipeline System Inc. is owned by Chevron Corp., Texaco Inc., Unocal Corp., and Anschutz Co. 
In September 1994, Governor Wilson signed a bill to permanently ban oil drilling in state waters along California's coastline. It contained an exemption for a Mobil project involving slant drilling from onshore. ${ }^{11}$ The bill was authored by a Santa Barbara Assemblyman, who reflected his county's long-standing objection to offshore oil and gas production off its coast. The bill was opposed in principle by the oil industry; however, the industry has shown little interest in drilling offshore in recent years and has relinquished the largest share of leases obtained from early Federal OCS sales without drilling them. A ban was placed on the sale of leases in federal waters off California by President George Bush in 1992.

\section{Natural Gas Production}

About 15\% of California's gas supply comes from production within the state. About two thirds of the total consists of natural gas produced in association with oil production, and the remainder is so-called "nonassociated" gas. The latter comes principally from gas wells in the Sacramento River delta area. Production of "associated" gas is also largely from onshore fields. Both associated and nonassociated gas production peaked in $1985,{ }^{9}$ at which time their contribution to the total California production was approximately the same. In the intervening years production from both sources has declined, and by 1994 combined production was 63\% of 1985 production. The largest declines have been registered in nonassociated gas. The total amount of gas produced in connection with oil production has been bolstered by production in the federal offshore areas, where new discoveries have come on line.

\section{OIL AND NATURAL GAS SUPPLY}

\section{Oil Supply}

The source of oil supplies changed little from 1993. Slightly more than half of the state's petroleum supply was imported; the remainder was from state onshore (77\%), state offshore (6\%), and federal offshore (17\%) production. Of the imported oil, the bulk consisted of North Slope, Alaska, crude oil that was tankered from Valdez, Alaska. Foreign imports, which made up $8 \%$ of total supply and about $15 \%$ of total imports to the state, came primarily from Canada and Indonesia.

\section{Natural Gas Supply}

The steady decline in California natural gas production, fuel switching driven by California's stringent air pollution regulations, and the general growth of gas use in residential and commercial sectors have required large increases in out-of-state imports to meet California demand. Gas production is about half of its historic highs set between 1966-8. The offsetting imports have grown so that they comprised $88 \%$ of total supply in 1994, with $62 \%$ from the Southwest U. S. and 26\% from Canada (Figure 1). 
Pipeline construction in California slowed in 1994 after a period of rapid growth in pipeline capacity. The two biggest projects completed in 1993 were (1) the Kern River pipeline, a direct link to Rocky Mountain gas reserves, which provide gas for the enhanced oil recovery operations and cogeneration in Southern California, and (2) additional capacity on Pacific Transmission Company's 805-mile pipeline from Canada. Pacific Transmission Company is a wholly owned subsidiary of Pacific Gas and Electric Co. (PG\&E), the utility that services Northern California. Because the Canadian pipeline was opened at the end of 1993, its effect was not felt until 1994, when imports from Canada jumped 48\%. Exploration and development in Canada's gas provinces

have surged since 1992, and Canada's markets are expected to grow such that it will be a significant supplier in future years. ${ }^{12}$

\section{ELECTRICAL POWER}

\section{Source of Supply}

Electricity distributed by California utilities derives from numerous sources: imports from out-of-state generators (principally from the southwest U.S.); utility generators utilizing fossil fuels, hydropower, geothermal energy, and nuclear reactors; and purchases from nonutility generators using a variety of fuels (Table 7). Utility generating capacity by fuel source is given in Table $8 .^{13}$

\section{Nuclear Power}

California utilities operate two nuclear plants within the state and have a $15.5 \%$ interest in the Palo Verde plant at Phoenix, AZ. Each of the two in-state nuclear installations consists of two $\sim$ 1000-MW nuclear reactors, and collectively they produce 
Table 7. Sources of California Utilities' Distributed Electricity - 1994.

Source

Imports

Out-of-state coal and nuclear facilities: Purchases:

Fossil fuels

Natural gas:

Oil:

Nuclear power (in-state)

Hydropower

Geothermal power

Windpower

Cogeneration

Biomass, solar, and coal
Net electrical energy

(trillion Btu)

172

66

106

166

159

7

TOTAL

Table 8. California utility (in-state) electrical generating capacity. ${ }^{13}$

\section{Primary energy source}

Petroleum

Gas

Water

Nuclear

Other (principally geothermal)

\section{Capacity*}

(GWe)

2.11

21.96

13.25

4.31

1.67

TOTAL

43.30

774

135

54

12

96

31 
about $10 \%$ of the electricity generated within the state. The total contribution increased again in 1994. Both the Diablo Canyon nuclear plant in San Luis Obispo County and the San Onofre Nuclear Generating Station in San Diego County were built with large cost overruns. In the case of Diablo Canyon, the California Public Utilities Commission (CPUC) declined to allow the cost overruns to be passed onto consumers and instead in 1988 negotiated a novel rate settlement with the utility-owner (PG\&E) that tied the return on investment to performance and electrical output rather than the usual cost basis. Better-than-expected performance at Diablo Canyon has led to a steady escalation in the price per $\mathrm{kWh}$ received in keeping with the terms of the settlement. In 1994 it was 11.89 cents. In January 1995, attorneys representing consumer groups filed a motion with the CPUC to reduce the price of power at Diablo Canyon to 11.00 cents per $\mathrm{kWh}$ from the increase to 12.15 cents per $\mathrm{kWh}$ scheduled for 1995 according to the settlement formula. ${ }^{14}$ These high rates are a contributing factor in making the utility's charges to customers among the highest in the nation. The proposed decrease reflects the view that the 1988 rate settlement had resulted in an unreasonably high rate of return. The excellent performance history at Diablo Canyon was unanticipated. It relates to the newness of the installation and to the concerted effort on the part of the utility to improve performance. The latter was accomplished in large part by reducing the time required to refuel the reactors. Refueling time has fallen substantially over the history of the plants-from an average of 64 days in 1989 for the two units to 45 days in 1994. Each unit produces about $\$ 3$ million of revenues per day at full power operation, and a $1 \%$ increase in the combined annual capacity factor for the two units increases revenues by approximately $\$ 21$ million based upon 11 cents/kWh. ${ }^{15}$ Because both units were refueled in 1994, the combined capacity factor was down as compared to the previous year when only one was refueled.

Both Southern California Edison Co. (SCE) and San Diego Gas and Electric Co. $(\mathrm{SDG} \& \mathrm{E}),{ }^{15}$ who jointly own the San Onofre Nuclear Generating Station, requested permission from the CPUC to put in place a performance-based plan to recover costs to replace the existing, traditional cost-basis method. Both wish to recover their costs at a faster rate in order to be in a better position to enter the competitive electrical market that is on the horizon. The CPUC ruled favorably in the case of both proposals. ${ }^{16}$

\section{Hydropower}

The modest contribution of in-state hydropower to the state's supply (shown in Figure 1) belies the important role water-generated electricity plays in California. The bulk of the imports coming into the state from the Pacific Northwest and the Southwest are from the hydroelectric resources of the Bonneville Power Administration and the Western Area Power Administration respectively. The latter administers the federally owned Glen Canyon and Hoover Dams.

The amount of hydroelectricity generated within the state declined in 1994 (Figure 1 and 2) because of a large decline in the 1993-1994 rainfall (July 1 to June 30) following the very wet 
1992-1993 season. A return to the drought conditions that prevailed earlier was not suggested because rains in late 1994 indicated a return to normalcy.

\section{Nonutility Generation}

The important role that nonutility generation plays in the electrical supply of the state (Table 9) has been influential in the decision of the CPUC to press for deregulation of the state's utilities. In California, nonutility generators consist of cogenerators whose fuel of choice is overwhelmingly natural gas. ${ }^{17}$ The next largest contributions to nonutility supply are made by wind generators and geothermal operators. Nonutility suppliers have traditionally sold their electricity to the publicly owned utilities at regulated rates and have never had the opportunity to compete for customers.

California's nonutility generators lead the nation in sales to the public utilities. Although the gross output of Texas' nonutility generators approaches that of California, less than half of the power produced flows into the state's electrical grid. In contrast to the California situation (Table 9), in Texas the bulk of the electricity is used by the power producing facilities themselves.

\section{Table 9. Production of electricity by California utilities and nonutilities. ${ }^{17}$ (billion $\mathrm{kWh}$ )}

\begin{tabular}{lrrr} 
& \multicolumn{2}{c}{ Year } & \\
& $\mathbf{1 9 9 2}$ & $\mathbf{1 9 9 3}$ & $\mathbf{1 9 9 4}$ \\
& & & \\
& 119.3 & 125.8 & 126.7 \\
Net generation by public utilities & & & \\
& & & \\
Gross* generation by nonutilities & 67.0 & 62.8 & 63.2 \\
Receipts (purchases, exchanges, etc.) & 4.4 & 53.4 & 53.1 \\
Deliveries to utilities & 50.5 & 12.4 & 13.4 \\
Facility use & 13.1 & & \\
\hline
\end{tabular}

*Note: The gross-to-net generation conversion factor varies from 0.99 to 0.97 depending on the type of prime mover. $^{17}$

\section{Alternative Sources of Electricity}

Geothermal

Geothermal energy is often included in discussions of renewable forms of energy, and it comes as a surprise to many that it is subject to depletion similar to that associated with oil and gas reserves. For the past several years evidence of depletion has been apparent in the steam production at The Geysers near Calistoga, CA, the world's largest geothermal field. Reinjection of condensed vapor after it has been used to power electricity-generating steam turbines has been 
ongoing at the field for decades; however, it has only slowed but not reversed the steady decline in steam production at the field. The gross amount of steam produced in 1994 (Table 10) is $70 \%$ of the historical high set in 1987. Twenty-three wells were formally abandoned in 1994.

\section{Table 10. Principal geothermal installations in California (1994). ${ }^{9}$}

Field

Coso Hot Springs

East Mesa

The Geysers

Heber

Mono-Long Valley

Salton Sea

Wendell-Amedee

Total
Gross installed capacity (MWe)

$19921993 \quad 1994$

$260 \quad 260 \quad 260$

130

1900

52

40

240

3

2625
$260 \quad 260$

$125 \quad 110$

19001900

$85 \quad 90$

40

240

Steam/fluid production

(billions of kilograms) $\begin{array}{lll}1992 & 1993 & 1994\end{array}$

$\begin{array}{lll}41.2 & 47.7 & 43.3\end{array}$

$\begin{array}{lll}97.6 & 97.8 \quad 90.6\end{array}$

$88.5 \quad 84.4 \quad 78.4$

$29.5 \quad 41.7 \quad 53.9$

$\begin{array}{lll}24.6 & 23.5 & 23.6\end{array}$

$\begin{array}{lll}78.0 & 77.8 & 77.8\end{array}$

$\begin{array}{lll}8.5 & 7.9 & 7.3\end{array}$

Approximately one-third of the condensed vapor at The Geysers is reinjected; the remainder is lost to the atmosphere. ${ }^{9}$ In an effort to increase the amount of injected fluid, a joint project between the city of Clearlake and the operators at the field was given the go-ahead in 1994. The plan is to build a pipeline to carry treated waste water from Clearlake to the field, where it will be injected to increase steam production.

The state's other geothermal fields produce hot water or brine as opposed to vapor and thus require more complex technologies to convert the energy to electricity. Starting in 1994, zinc was a by-product of operations at the J. J. Elmore plant in the Salton Sea field. The almost pure metal is extracted from the brines by ion-exchange methods before it is reinjected into the ground. In general, recovery of the fluids is more complete in water-dominated geothermal fields, and hence larger percents of the amounts produced are reinjected. Nonetheless water-dominated systems are also subject to depletion, as evidenced by the retirement of a 13.4-MW (gross) binary plant in the East Mesa geothermal field in 1994. One bright spot was increased production in the Heber field in Southern California (Table 10), where the number of producing wells has more than doubled between 1992 and 1994. 


\section{Solar Electricity}

The amount of energy captured by solar thermal collectors goes largely unmonitored in the United States. Some estimates are possible from the number of collectors shipped from manufacturers since 1974. Assuming a 50\% overall efficiency and exposure to 1,500 Btu insolation per square foot per day, the solar contribution has been calculated at 0.06 quads (quadrillion Btu) for 1994. ${ }^{18}$ Reference to Figures 1, 2, and 3 can put this number into perspective.

Although it is not possible to know California's contribution to this total, it is probably large judging by the state's share of the number of solar photovoltaic installations in the United States. Combined utility and nonutility installed capacity of solar electric units in California is 362MW, which represents more than $95 \%$ of the total installed in the United States. ${ }^{18}$ Gross electrical generation in 1994 from solar modules in California is estimated at 811 million $\mathrm{kWh},{ }^{18}$ almost all of which was from nonutility power producers.

\section{Windpower}

California remains the largest producer of windpower in the world, although its share has fallen below $50 \%$ of grid-connected capacity from a high estimated at $70 \%$. The decline in California's share is due primarily to increased utilization in other parts of the world. According to the California Energy Commission, during 1994 both the amount of electricity generated (3.27 billion $\mathrm{kWh}$ ) and total installed capacity in the state were at 1993 levels. The number of turbines in operation declined because of the retirement of older, less efficient wind turbines. Because some were replaced by newer models, the result was an overall increase in the statewide capacity factor, which reached $23 \%$, as compared to $30 \%$ that is estimated to be possible. (Capacity factor is the ratio of actual energy output to the possible output if operated 24 hours a day at full rated power).

The two largest concentrations of wind turbines in California are near the Altamont Pass in Northern California and the Tehachapi Pass area in Kern County in Southern California (Table 11). ${ }^{19}$ The production of power in the Altamont Pass area is more affected by seasonal winds than the Tehachapi area; however, both areas register uneven monthly output. Statewide, approximately $73 \%$ of wind-generated electricity is produced between April 1 and September 30 when the rising hot air in the inland valleys is replaced by eastward-moving, cooler coastal air. The match with high electrical demand during the summer months is good but not perfect.

Table 11. Windpower installations in California as of January 1. ${ }^{19}$

\section{Location}

Capacity $\left(\mathrm{MW}_{\mathrm{e}}\right)$ 1992199319941995
Number of turbines $\begin{array}{llll}1992 & 1993 & 1994 & 1995\end{array}$ 


$\begin{array}{lcccccccc}\begin{array}{c}\text { Altamont Pass area, } \\ \quad 45 \text { miles east of } \\ \text { San Francisco }\end{array} & 704 & 683 & 638 & 625 & 6818 & 6451 & 5952 & 5901 \\ \begin{array}{c}\text { San Gorgonio Pass, } \\ \quad \text { Riverside County } \\ \text { near Palm Springs }\end{array} & 255 & 263 & 267 & 274 & 3581 & 3646 & 3683 & 3092 \\ \begin{array}{c}\text { Tehachapi Pass, } \\ \quad \text { Kern County }\end{array} & 644 & 632 & 627 & 630 & 5221 & 4992 & 4908 & 4801 \\ \begin{array}{c}\text { Carquinez Strait, } \\ \quad \text { Solano County }\end{array} & 60 & 60 & 60 & 65 & 600 & 600 & 600 & 617 \\ \begin{array}{c}\text { Pacheco Pass, } \\ \quad \text { San Benito County }\end{array} & 16 & 16 & 16 & 16 & 167 & 167 & 167 & 166 \\ \quad & 1679 & 1654 & 1608 & 1610 & 16,387 & 15,856 & 15,310 & 14,577\end{array}$

Capacity factor*

20

1920 23

*Capacity factor is defined as the ratio of actual energy output to the amount of energy a project would produce if it operated at full rated power for 24 hours per day within a given time period.

Pollution-free windpower has always been a favorite with environmentally conscious Californians. All through the 1980s the industry enjoyed generous tax credits and mandated purchase contracts with the regulated utilities, which guaranteed high prices for the power, up to 14 cents per kilowatt hour. The then-infant industry thrived; however, many of the lucrative contracts with the utilities have lapsed, and the new standard contracts are designed less to be subsidies than to be competitive with other types of electrical generation. Nonetheless, in 1993 the CPUC ordered the state's investor-owned utilities to hold auctions for the purchase of $1400 \mathrm{MW}$ of power from independent generators. ${ }^{20}$ Among the winners were several windpower firms. The three public utilities protested the auction on several grounds; they argued that they were being forced to buy capacity above their "avoided costs," and secondly, that several have excess generating capacity of their own. One utility actually pays some of its current wind producers under contract not to deliver their power. ${ }^{21}$ Their principal complaint with windpower is that its time of arrival is not necessarily coincident with demand. In March 1995, the Federal Energy Regulatory Commission ruled that the auction was illegal because the CPUC had not correctly calculated the utilities' avoided costs, and further that it was in conflict with its own proposal on restructuring and deregulating the utilities. ${ }^{22}$ The ruling promises to have long-reaching consequences to all of the electrical generating facilities that qualify to receive benefits under the Public Utility Regulatory Policies Act. 
Despite the U.S. Department of Energy's forecast that the nation's windpower will increase about 10\% per year between 1994 and 2015, ${ }^{23}$ there were indications of problems within the industry at the end of 1994. Kenetech, the second largest operator, posted substantial losses and laid off some of its employees, resulting in a dramatic fall in the price of its stock. ${ }^{24}$ It is questionable whether the company could have met the terms of its contracts with the state's three utilities that it had won at the "illegal" auction held in late 1993.

\section{Deregulation of the California Electric Power Industry}

Restructuring of the electrical power industry was made possible by two federal acts, The Public Utility Regulatory Policies Act of 1978 and the Energy Policy Act of 1992. The first encouraged independent power production by requiring the public, investor-owned, utilities to purchase nonutility-generated electricity, and the second required the public utilities to transmit electricity generated by independent power producers. Collectively these acts were designed to give independent power producers access to retail customers and to allow customers to choose among suppliers.

However,

as

\footnotetext{
"“Avoided costs," are costs a utility would have to incur to provide additional electrical capacity.
}

long as rates charged by the public utilities were regulated by the CPUC, traditional suppliers potentially could find themselves in a noncompetitive situation. Hence California was one of the first states to move toward deregulation of the industry. After two years of study, in April 1994 the CPUC issued its proposal on how to restructure the electric services industry and solicited comment in a series of hearings that began several months later. ${ }^{25}$ The proposal was designed to enable the utilities to meet the impending competition, reduce administrative costs of regulation, and lower the cost of service, which is on average the highest in the nation. The "blueprint" proposed that beginning January 1, 1996, consumers who receive service of over 50 kilovolts have direct access to electricity from power providers. Within six years all electric consumers would be given the choice of providers, including residential users. In those areas where competition does not exist, traditional regulation would be replaced with performance-based ratemaking.

The hearings in June 1994 brought out the complexities of the proposed deregulation. The three major public utilities in the state were concerned about (1) recouping their capital investment in existing facilities associated with erosion of their traditional market and (2) who would bear the transition costs, which are expected to be large. The environmental groups were concerned about the future funding of utility-sponsored programs designed to reduce consumption and to promote energy conservation. These programs have been financed by rate increases authorized by the 
CPUC. The nonutility generators, who have sold their power to the utilities under mandate from the CPUC at rates that sometimes exceeded the cost of utility-generated power, were concerned with their survival in a competitive market.

The most troublesome issues had to do with the specifics of how to manage the electric supply. Here the three major utilities differed; Southern California Edison Co. (SCE) and San Diego Gas and Electric Co. (SDG\&E) recommended establishment of a wholesale power pool to provide back-up service to all users, and Pacific Gas and Electric Co. (PG\&E) advocated free markets and bilateral contracts between providers and customers. Ultimately the CPUC commissioners approved the power pool; however, by 1995 the decision was being reconsidered and several hybrid plans were gaining acceptance. ${ }^{26}$ Not waiting for the decision, in December 1994 PG\&E announced a first-of-its-kind transmission agreement allowing a large, out-of-state, independent power producer to sell wholesale electricity throughout PG\&E's service area. ${ }^{27}$

Yet to be resolved was the role to be played by the Federal Energy Regulatory Commission, which has jurisdiction over interstate power transactions. Because it is almost certain that out-of-state power producers will enter the California market, federal and state regulations will have to be brought into conformance. It was noted in the June 1994 hearings that the CPUC plan necessitates amending the Public Utility Regulatory Policies Act, which contains provisions dealing with mandatory power purchases on the part of the utilities as well. ${ }^{28}$

Although the proposal to be submitted to the California Legislature and the Governor for approval was far from finalized in 1994, the major public utilities individually began to take steps to improve their position to meet a future competitive market. Cutting costs was chief amongst the steps, but they made numerous proposals to the CPUC regarding rates.

SCE and SDG\&E, co-owners of the San Onofre nuclear plant, in separate decisions were allowed to speed up the recovery of costs related to the station. SDG\&E proposed using a new performance-based system. ${ }^{29}$ PG\&E proposed to reduce its rates that are associated with the Diablo Canyon nuclear plant over the next five years. The request was unusual because the utility had an agreement with the CPUC whereby it could increase rates over the next five years. ${ }^{30}$ On another tack to meet future competition, PG\&E continued to buy independent power plants. The purchases have been negotiated by U.S. Generating Co., a partnership consisting of PG\&E Enterprises, a nonutility unit of the company, and Bechtel Enterprises, an arm of the giant construction company. Acquisitions in 1994 resulted in U.S. Generating Co.'s moving from fourth to third place nationwide in the ranks of independent power producers. ${ }^{31}$ 


\section{APPENDIX A \\ Data Sources for California Energy Supply (1994)}

Production

Crude oil including federal

offshore and lease condensate

Associated and nonassociated natural gas (marketed, dry)

Electric utility fuel data

Electrical generation

Utility—oil, gas, hydro, nuclear,

Wind

Cogeneration and various small, nonutility power producers

\section{Imports}

Natural Gas

Foreign

Domestic

Crude oil

Foreign and domestic

Oil products

Foreign and domestic

Coal

Electrical power

Net exchange

Coal

\section{Exports}

Oil products

Foreign and domestic (not including bunkering fuel supplied at California ports)

\section{Source}

Ref. 9.

Ref. 12, Table 52,

Summary Statistics Natural Gas -California.

Ref. 17, Table 18,

Consumption Petroleum \& Gas to Produce Electricity.

Ref. 17, Table 13,

Net Generation Electric

Utilities by energy source.

Andrea Gough, California

Energy Commission, personal

communication, November 16, 1995.

Andrea Gough, California

Energy Commission, personal

communication, November 16, 1995.
Ref. 12, Table 9.

Ref. 12, Table 52.

Ref. 32, Table 5, 5-1, 5-2, 5-3, 5-4, California Petroleum Summary.

Ref. 32, Table 7, California

Fuels Market Petroleum Activity.

Ref. 33, Table 46, Coal Consumption by Census

Division and State.

Andrea Gough, California

Energy Commission, personal

communication, November 16, 1995.

Ibid. 


\section{APPENDIX B \\ Data Sources for California End Uses (1994)}

Net Storage

Natural gas

Ref. 12, Table 52.

$\underline{\text { Unaccounted for Natural Gas }}$

Ref. 12, Table 52.

\section{Transportation}

Crude oil

Gasoline, aviation and jet fuels

Taxable diesel fuel

(for public highways)

Vessel bunkering

(includes international bunkering)

Rail diesel

Military use

Natural gas

Pipeline fuel

Ref. 34.

Ref. 35, Table 4, Sales for

Transportation Use: Distillate Fuel Oil

End Use, 1994.

Ref. 35, Table 4 and 5.

Ref. 35, Table 4.

Ibid.

Ref. 12, Table 52,

Industrial, Government, Agriculture, etc.
Natural gas
Ref. 12, Table 52.
(includes lease and plant fuel)
Coal
Electricity
Ref. 33, Table 46.
Crude oil
Ref. 17, Table 4.
By difference.

Non Energy Applications

Crude oil and LPG

Asphalt

Ref. 36.

Petrochemical feedstock

Ref. 37, Table 41 (estimate) \&

Waxes, lubricating oils, medicinal uses, cleaning

Ref. 38, Table 12.

Ref. 32.

$\underline{\text { Residential and Small Commercial }}$

Natural gas

Ref. 12, Table 52.

Crude oil and other oils

(kerosene, residual, and distillate)

Ref. 35, Table 6, Sales of

Kerosene by End Use; Table 5,

Sales of Residual Fuel Oil by End

Use; Table 4, Sales of Distillate Fuel

LPG

Miscellaneous. "Off highway" Diesel Electricity
Oil by End Use.

Ref. 37, Tables 41-45 and Ref. 38,

Table 12.

Ref. 35, Table 4.

Ref. 17, Table 26. 


\section{APPENDIX C \\ Energy Balance for 1994 (Figure 1)}

\section{SUPPLY}

Electrical imports

Wind

Hydropower

Cogenerated electricity

Geothermal

Biomass, solar, coal, etc.

Nuclear

Natural gas

Less net additions to storage

Coal56

Petroleum

Total $\left(10^{12} \mathrm{Btu}\right)$

438

11

89

$-{ }^{\mathrm{a}}$

270

176

360

2235

$-5$

4170

$-574$

7226

2701

990

1158

553

240

4369

424

386

2211

1058

433

245

9

221

150

Geothermal $^{\mathrm{c}}$

290

Out-of-state elec. generation,

transmission losses and unaccounted

Cogeneration (included in industrial)

${ }^{\text {a}}$ Fuels included with petroleum and natural gas amounts.

${ }^{\mathrm{b}}$ Utility generation.

${ }^{\mathrm{c} C o m b i n e d ~ u t i l i t y ~ a n d ~ n o n u t i l i t y ~ g e n e r a t i o n . ~}$

${ }^{\mathrm{d}}$ Nonutility generation only. 


\section{APPENDIX D \\ Conversion Units and Assumed Conversion Efficiencies}

Energy Source

Electricity

Coal

Natural gas

Crude oil

Fuel oil

Residual

Distillate, including diesel

Gasoline and aviation gasoline

Kerosene and kerosene-type jet fuel

Asphalt

Road oil

Synthetic rubber and miscellaneous

LPG products
Conversion factor, $10^{6} \mathrm{Btu}$

3.415 per million $\mathrm{Wh}$

22.6 per short ton

1.05 per $\mathrm{Mcf}$

5.80 per barrel

6.287 per barrel

5.825 per barrel

5.253 per barrel

5.67 per barrel

6.636 per barrel

6.636 per barrel

4.01 per barrel

\section{Assumed Conversion Efficiencies of Primary Energy Supply}

Electric power generation

Hydropower

$90 \%$

Coal

$30 \%$

Geothermal

$18 \%$

Oil and gas

$33 \%$

Uranium

$32 \%$

Biomass

$12 \%$

Transportation use

$20 \%$

Residential/commercial use

$70 \%$

Industrial use

$75 \%$ 


\section{REFERENCES}

1. a. E. Behrin and R. Cooper, California Energy Outlook, Lawrence Livermore National Laboratory report UCRL-51966, Rev. 1 (1976).

b. I. Y. Borg, California Energy Flow in 1976, 1977, Lawrence Livermore National Laboratory report UCRL-52451 (1978) and UCID-18221 (1979) respectively.

c. A. L. Austin and S. D. Winter, U.S. Energy Flow Charts for 1950, 1970, 1980, 1985 and 1990, Lawrence Livermore National Laboratory report UCRL-51487 (1973).

d. I. Y. Borg and C. K. Briggs, California Energy Flow in 1978, 1979, 1980, 1981, 1982, $1983,1985,1986,1987,1988,1989,1990,1991,1992,1993$, Lawrence Livermore National Laboratory reports UCID-18760 (1980), UCID-18991 (1981), 18991-80 (1982), 18991-81 (1983), 18991-82 (1983), 18991-83 (1984), 18991-85 (1986), 18991-86 (1987), 18991-87 (1989), 18991-88 (1989), 18991-89 (1991), 18991-90 (1992), 1899191 (1993), 18991-92 (1994), 18991-93 (1995) respectively.

e. I. Y. Borg and C. K. Briggs, "California's Energy Supply and Demand in 1984," Annual Review of Energy 11, pp. 209-28 (1986).

2. I. Y. Borg and C. K. Briggs, U.S. Energy Flow-1994, Lawrence Livermore National Laboratory report UCID 19227-94 (Dec. 1995).

3. Electric Power Annual-1993, EIA/DOE-0348(93), p. 8, U.S. Department of Energy, Washington, DC (Dec. 1994).

4. California Economic Indicators, California Department of Finance, pp. 5-8, Sacramento, CA (Jan-Feb. 1995).

5. California Statistical Abstract-1995, Tables C-1, I-3, J-4, K-4, D-4, and D-13, California Department of Finance, Sacramento, CA (Nov. 1995).

6. Travel and Related Factors in California-Annual Summary 1994, California Department of Transportation, Sacramento, CA (1995).

7. Calfuels Plan-Developing an Infrastructure Plan for Alternative Fuel Vehicles, Publ. 500-94002, Table 3, California Energy Commission Staff Draft, California Energy Commission, Sacramento, CA (June 1994).

8. "California refiners face hurdle in federal, state RFG rules," Oil and Gas J., p. 23 (Oct. 10, 1994).

9. 1994 Annual Report of the State Oil \& Gas Supervisor, Publ. No. PRO6, California Department of Conservation, Sacramento, CA (1995).

10. “Transport woes threaten California production,” Oil and Gas J., p. 34 (May 23, 1994).

11. G. Lucas, "New law permanently bans drilling off coast," San Francisco Chronicle, p. A19 (Sept. 29, 1994).

12. Natural Gas Annual 1994, v. 1, DOE/EIA-0131(94/1), p. 20, U.S. Department of Energy, Washington, DC (Nov. 1995). 
13. Inventory of Power Plants in the United States 1994, DOE/EIA-0095(94), Table 20, U.S. Department of Energy, Washington, DC (Oct. 1995).

14. 1994 Financial and Statistical Report, Pacific Gas and Electric Co., San Francisco, CA (1995).

15. P. Newman, "SDG\&E pushing 'Pay-for-performance' plan at San Onofre," The Energy Daily 22, p. 4 (Sept. 15, 1994).

16. A. Salpukas, "Faster cost pass-through for California utility," The New York Times, p. D5 (May 26, 1994).

17. Electric Power Annual-1994, DOE/EIA-0348(94), v. I, Table 12 and v. II, Tables 57 and 60, U.S. Department of Energy, Washington, DC (July 1995 and Nov. 1995).

18. Renewable Energy Annual 1995, DOE/EIA-0603(95), U.S. Department of Energy, Washington, DC (Dec. 1995).

19. Wind Project Performance-1994 Summary, P500-95-003, California Energy Commission, Sacramento, CA (Aug. 1995).

20. J. Marshall, "Utility doesn't want to buy wind power," San Francisco Chronicle, p. D2 (July 25, 1994).

21. J. Marshall, "Power firm races into the wind," San Francisco Chronicle, p. 1 D1 (Aug. 29, 1994).

22. M. O'Driscoll, "RERC to California: BRPU a bust," The Energy Daily 23, p. 1 (Feb. 23, 1995).

23. Annual Energy Outlook 1996 with Projections to 2015, DOE/EIA-0383(96), Table A17, U.S. Department of Energy, Washington, DC (Jan. 1996).

24. H. Greenberg, "Gone with the wind? Kenetech insiders brace for the worst," San Francisco Chronicle, p. D1 (Dec. 12, 1995).

25. California Public Utilities Commission-Annual Report 1993-1994, California Public Utilities Commission, San Francisco, CA (1995).

26. B. A. Holden, "California's struggle shows how hard it is to deregulate utilities," Wall Street Journal, p. 15 (Nov. 28, 1995).

27. A. Pasztor, "PG\&E to announce novel agreement on transmission," Wall Street Journal, p. C25 (Dec. 6, 1994).

28. M. O'Driscoll, "The debate begins: California considers competitive future," The Energy Daily 22, p. 1 (June 15, 1994).

29. P. Newman, "SDG\&E pushing 'Pay-For-Performance' Plan at San Onofre," The Energy Daily 22, p. 4 (Sept. 15, 1994).

30. A. Salpukas, "Large California utility accepts rate-cut plan," The New York Times, p. A4 (Dec. 7, 1994). 
31. J. Marshall, "Latest PG\&E acquisition boosts its position as leader in energy market," San Francisco Chronicle, p. D1 (July 7, 1994).

32. Quarterly Oil Report, Annual Issue 1994, California Energy Commission, Sacramento, CA (May 1996).

33. Quarterly Coal Report, 4th Quarter 1994, DOE/EIA-0121(94), U.S. Department of Energy, Washington, DC (May 1995).

34. State Energy Data Report-Consumption Estimates-1994, Julia Hutchins, U.S. Department of Energy, Washington, DC, personal communication (May 8, 1996).

35. Fuel Oil and Kerosene Sales 1994, DOE/EIA-0535(94), U.S. Department of Energy, Washington, DC (Sept. 1995).

36. Asphalt Usage 1994, United States and Canada, Asphalt Institute, Lexington KY (Nov. 1995).

37. State Energy Data Report-Consumption Estimates (1993), DOE/EIA-0214(93), U.S. Department of Energy, Washington, DC (July 1995).

38. Petroleum Supply Annual-1994, v. 1, DOE/EIA-0340(94/1), U.S. Department of Energy, Washington, DC (May 1995). 


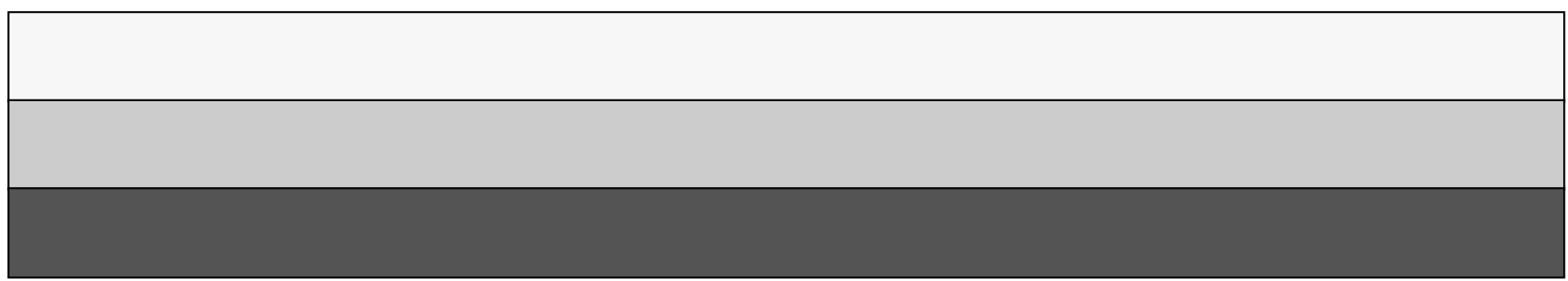

